\title{
PENENTUAN FUNGSI JARINGAN JALAN SISTEM SEKUNDER DI KAWASAN PERKOTAAN STUDI KASUS PERKOTAAN CIANJUR
}

\author{
ILHAM \\ Jurusan Teknik Sipl Fakultas Teknik \\ Universitas Suryakancana Cianjur \\ ilhamipong@yahoo.co.id
}

\begin{abstract}
ABSTRAK
Berdasarkan sifat dan pergerakan lalu lintasnya, fungsi jalan terdiri dari arteri, kolektor, lokal, dan lingkungan. Fungsi jalan ini terdapat berada pada sistem jaringan jalan primer dan sekunder

Di wilayah kabupaten Cianjur terdapat jaringan jalan nasional sepanjang 212,45 km, terdiri dari jalan arteri primer sepanjang $47,48 \mathrm{~km}$, dan jalan kolektor primer (Kolektor 1) sepanjang 164,97 km, jaringan jalan provinsi sepajang 137,85 km yang berfungsi sebagai jalan kolektor primer (kolektor 2) dan jalan kabupaten sepanjang lebih dari $1300 \mathrm{~km}$.

Jalan kabupaten tersebut terdiri dari jaringan jalan yang menghubungkan antar pusat-pusat kegiatan di wilayah kabupaten Cianjur dan juga berada di dalam kawasaan perkotaan.

Berdasarkan data inventarisasi jaringn jalan pada Dinas Pekerjaan Umum dan Penataan Ruang Kabupaten Cianjur, lebih dari $100 \mathrm{~km}$ panjang jalan tersebut terdapat kawasan perkotaan.

Oleh sebab itu jaringan jalan yang berada kawasan perkotaan tersebut dipandang perlu untuk ditentukan fungsi dalam sistem jaringan jalan sekunder. Untuk studi kasus ini yang akan ditentukan fungsinya adalah ruas-ruas jalan yang berada di kawasan perkotaan Cianjur
\end{abstract}

Kata Kunci: Klasifikasi fungsi jalan, system jaringan jalan, Arteri Primer, Kolektor Primer, Lokal Primer, Lingkungan Primer, Arteri Sekunder, Kolektor Srkunder, Lokal Sekunder, Lingkungan Sekunder.

\section{PENDAHULUAN}

Jalan adalah prasarana transportasi darat yang meliputi segala bagian jalan, termasuk bangunan pelengkap dan perlengkapannya yang diperuntukkan bagi lalu lintas, yang berada pada permukaan tanah, di atas permukaan tanah, di bawah permukaan tanah dan/atau air, serta di atas permukaan air, kecuali jalan kereta api, jalan lori, dan jalan kabel.

Jalan sebagai salah satu prasarana transportasi mempunyai peranan penting untuk mewujudkan sasaran pembangunan seperti pemerataan pembangunan dan hasil-hasilnya, pertumbuhan ekonomi, dan perwujudan keadilan sosial bagi seluruh rakyat Indonesia. Sebagai bagian dari sistem transportasi nasional, jalan mempunyai peranan penting terutama dalam mendukung ekonomi, sosial budaya, lingkungan, politik, serta pertahanan keamanan. Dari aspek ekonomi, jalan berfungsi untuk memperlancar arus distribusi barang dan jasa serta berperan dalam peningkatan kualitas hidup dan kesejahteraan masyarakat. Dari aspek sosial budaya, keberadaan jalan membuka cakrawala masyarakat yang dapat menjadi wahana perubahan sosial, membangun toleransi, dan mencairkan sekat budaya. Dari aspek lingkungan, keberadaan jalan diperlukan untuk mendukung pembangunan berkelanjutan. Dari aspek politik, keberadaan jalan menghubungkan dan mengikat antar wilayah, sedangkan dari aspek pertahanan keamanan, keberadaan jalan memberikan akses dan mobilitas dalam penyelenggaraan sistem pertahanan dan keamanan. Selain daripada itu, pengembangan prasarana transportasi jalan juga ditujukan untuk membuka akses/hubungan antar satu wilayah dengan wilayah lain.

Di wilayah kabupaten Cianjur berdasarkan Keputusan Menteri Pekerjaan Umum dan Perumahan Rakyat Nomor : 290/KPTS/M/2015 Tentang Penetapan Ruas Jalan Menurut Sttausnya Sebagai Jalan Nasional terdapat sekitar 212,450 km panjang jalan nasional yang terdiri dari Jalan Arteri Primer sepanjang $47,48 \mathrm{~km}$ dan kolektor primer sepanjang 164,97 km, dan berdasarkan Keputusan Gubernur Jawa Barat Nomor 620/Kep.1530-Admek/2011 Tentang Penetapan Ruas-ruas Jalan Menurut Statusnya Sebagai Jalan Provinsi, terdapat sekitar 137,85 km panjang jalan provinsi dengan fungsi jalan Kolektor-2, serta berdasarkan keputusan Bupati Cianjur Nomor 620/Kep.168-Binamarga/2013 Tentang Penetapan Status Ruas Jalan Kabupaten, terdapat panjang jalan kabupaten sepanjang 1.301,697 km. Dari panang jalan kabupaten tersebut, sekitar Panjang jalan100 km berada dikawasan perkotaan. Ruas-ruas jalan 
kabupaten tersebut belum ditetapkan fungsinya. Sehingga dipandang perlu untuk mengkaji fungsi dari jaringan jalan kabupeten yang berada dikawaan perkotaan tersebut khususnya yang berada dikawasan perkotaan Cianjur, agar dapat ditetapkan fungsinya.

\section{STUDI PUSTAKA}

\section{a. Pusat Kegiatan}

Berdasarkan Peraturan Pemerintah Nomor 26 Tahun 2008 tentang Rencana Tata Ruang Wilayah Nasional yang telah dirubah dengan Peraturan Pemerintah Nomor 13 Tahun 2017 Tentang Perubahan Atas Peraturan Pemerintah Nomor 26 Tahun 2008 tentang Rencana Tata Ruang Wilayah Nasional, sistem perkotaan nasional terdiri atas: Pusat Kegiatan Nasional (PKN), Pusat Kegiatan Wilayah (PKW), dan Pusat Kegiatan Lokal (PKL).

- Pusat Kegiatan Nasional (PKN) adalah kawasan perkotaan yang berfungsi untuk melayani kegiatan skala internasional, nasional, atau beberapa provinsi.

- Pusat Kegiatan Strategis Nasional (PKSN) adalah kawasan perkotaan yang ditetapkan untuk mendorong pengembangan kawasan perbatasan negara.

- Pusat Kegiatan Wilayah (PKW) adalah kawasan perkotaan yang berfungsi untuk melayani kegiatan skala provinsi atau beberapa kabupaten/kota.

- Pusat Kegiatan Lokal (PKL) adalah kawasan perkotaan yang berfungsi untuk melayani kegiatan skala kabupaten/kota atau beberapa kecamatan.

Berdasarkan Lampiran II Peraturan Menteri Agraria Dan Tata Ruang/ Kepala Badan Pertanahan Nasional Nomor 1 Tahun 2018 Tentang Pedoman Penyusunan Rencana Tata Ruang Wilayah Provinsi, Kabupaten Dan Kota, sistem perkotaan di wilayah kabupaten terdiri dari:

- Pusat Kegiatan Nasioanal (PKN) yang berada di wilayah kabupaten;

- Pusat Kegiatan Wilayah (PKW) yang berada di wilayah kabupaten;

- Pusat Kegiatan Lokal (PKL) yang berada di wilayah kabupaten;
- Pusat Kegiatan Strategis Nasional PKSN yang berada di wilayah kabupaten; dan

- Pusat-pusat lain di dalam wilayah kabupaten yang wewenang penentuannya ada pada pemerintah daerah kabupaten.

Pusat-pusat kegiatan di dalam wilayah kabupaten yang kewenangan penentuannya oleh pemerintah kabupaten terdiri dari:

- Pusat Pelayanan Kawasan (PPK) merupakan kawasan perkotaan yang berfungsi untuk melayani kegiatan skala kecamatan atau beberapa desa; dan

- Pusat Pelayanan Lingkungan (PPL) merupakan pusat permukiman yang berfungsi untuk melayani kegiatan skala antar desa.

\section{b. Sistem Jaringan Jalan}

Berdasarkan Undang-undang Nomor 38 Tahun 2004 tentang Jalan, Jalan umum dikelompokkan menurut sistem, fungsi, status, dan kelas.

Menurut Peraturan Pemerintah Nomor 34 Tahun 2006 tentang Jalan, sistem jaringan jalan merupakan satu kesatuan jaringan jalan yang terdiri dari sistem jaringan jalan primer dan sistem jaringan jalan sekunder yang terjalin dalam hubungan hierarki.

\section{1) Sistem Jaringan Jalan Primer}

Sistem jaringan jalan primer disusun berdasarkan rencana tata ruang nasional, provinsi, kabupten/kota dan pelayanan distribusi barang dan jasa untuk pengembangan semua wilayah di tingkat nasional, dengan menghubungkan semua simpul jasa distribusi yang berwujud pusat-pusat kegiatan sebagai berikut :

- Menghubungkan secara menerus pusat kegiatan nasional (PKN), pusat kegiatan wilayah (PKW), pusat kegiatan lokal (PKL) sampai kepusat kegiatan lingkungan (PKLing)

- Menghubungkan antra pusat kegiatan nasional (PKN).

Untuk melayani lalu lintas menerus maka ruas-ruas jalan dalam sistem jaringan jalan primer tidak terputus walaupun memasuki kawasan perkotaan.

2) Sistem Jaringan Jalan Sekunder 
Sistem jaringan jalan sekunder disusun berdasarkan rencana tata ruang wilayah kabupaten/kota dan pelayanan distribusi barang dan jasa untuk masyarakat di dalam kawasan perkotaan yang menghubungkan secara menerus kawasan yang mempunyai fungsi primer, fungsi sekunder kesatu, fungsi sekunder kedua, fungsi sekunder ketiga, dan seterusnya sampai ke persil.

- Kawasan yang mempunyai fungsi primer (F1) adalah kawasan perkotaan yang mempunyai fungsi pelayanan, baik untuk kawasan perkotaan maupun untuk wilayah di luarnya.

- Kawasan yang mempunyai fungsi sekunder adalah kawasan perkotaan yang mempunyai fungsi pelayanan hanya dalam wilayah kawasan perkotaan yang bersangkutan.

- Kawasan fungsi sekunder kesatu (F2.1) adalah kawasan perkotaan yang mempunyai fungsi pelayanan seluruh wilayah kawasan perkotaan yang bersangkutan.

- Kawasan fungsi sekunder kedua (F2.2) adalah kawasan perkotaan yang mempunyai fungsi pelayanan yang merupakan bagian dari pelayanan kawasan fungsi sekunder kesatu.

- Kawasan fungsi sekunder ketiga (F2.3) adalah kawasan perkotaan yang mempunyai fungsi pelayanan yang merupakan bagian dari pelayanan kawasan fungsi sekunder kedua.

- Persil adalah sebidang tanah dengan ukuran tertentu untuk keperluan perumahan atau kegiatan lainnya.

Kawasan yang mempunyai fungsi primer dan kawasan yang mempunyai fungsi sekunder harus tersusun secara teratur dan tidak terbaurkan. Fungsi primer, fungsi sekunder kesatu, serta fungsi sekunder kedua dan seterusnya terikat dalam satu hubungan hierarki.

\section{c. Fungsi Jalan}

Menurut Peraturan Pemerintah Nomor 34 Tahun 2006 tentang Jalan, berdasarkan sifat dan pergerakan pada lalu lintas dan angkutan jalan, fungsi jalan dikelompokkan ke dalam jalan arteri, jalan kolektor, jalan lokal, dan jalan lingkungan.

1) Jalan arteri : merupakan jalan umum yang berfungsi melayani angkutan utama dengan ciri perjalanan jarak jauh, kecepatan rata-rata tinggi, dan jumlah jalan masuk dibatasi secara berdaya guna.

2) Jalan kolektor : merupakan jalan umum yang berfungsi melayani angkutan pengumpul atau pembagi dengan ciri perjalanan jarak sedang, kecepatan ratarata sedang, dan jumlah jalan masuk dibatasi.

3) Jalan lokal : merupakan jalan umum yang berfungsi melayani angkutan setempat dengan ciri perjalanan jarak dekat, kecepatan rata-rata rendah, dan jumlah jalan masuk tidak dibatasi.

4) Jalan lingkungan : merupakan jalan umum yang berfungsi melayani angkutan lingkungan dengan ciri perjalanan jarak dekat, dan kecepatan rata-rata rendah.

Fungsi jalan tersebut terdapat pada sistem jaringan jalan primer dan sistem jaringan jalan sekunder.

Jaringan jalan yang terdapat pada sistem jaringan primer dinyatakan sebagai jalan arteri primer, jalan kolektor primer, jalan lokal primer, dan jalan lingkungan primer.

1) Jalan arteri primer adalah secara berdaya guna :

- menghubungkan antar-PKN; atau

- menghubungkan antara PKN dengan PKW.

2) Jalan kolektor primer adalah secara berdaya guna :

- menghubungkan antara PKN dengan PKL;

- menghubungkan antar-PKW; atau

- menghubungkan antara PKW dengan PKL.

3) Jalan lokal primer adalah secara berdaya guna : 
- menghubungkan PKN dengan PKLing;

- menghubungkan PKW dengan PKLing;

- menghubungkan antar-PKL; atau

- menghubungkan PKL dengan PKLing, serta

- menghubungkan antar-PKLing.

4) Jalan lingkungan primer adalah :

- menghubungkan antarpusat kegiatan di dalam kawasan perdesaan (PKKw); dan

- jalan di dalam lingkungan kawasan perdesaan.

Berdaya guna dimaksudkan bahwa jalan yang digunakan memerlukan biaya perjalanan terendah yang ditunjukkan dengan dengan waktu tempuh tercepat, faktor hambatan samping kecil, dan kondisi jalan baik.

Jaringan jalan yang terdapat pada sistem jaringan sekunder dinyatakan sebagai jalan arteri sekunder, jalan kolektor sekunder, jalan lokal sekunder, dan jalan lingkungan sekunder.

Berdasarkan Peraturan Pemerintah Nomor 34 Tahun 2006 tentang Jalan dan Pedoman Penentuan Klasifikasi Fungsi Jalan Di Kawasan Perkotaan Pd T-18-2004-B, Ciriciri jalan sekunder diantaranya:

1) Jalan arteri sekunder adalah :

- menghubungkan kawasan primer (F1) dengan kawasan sekunder kesatu (F2.1);

- menghubungkan antar kawasan sekunder kesatu (F2.1);

- menghubungkan sekunder kesatu (F2.1) dengan kawasan sekunder kedua (F2.2);

\section{d. Penetapan Sistem Jaringan Jalan dan Fungsi Jalan}

\section{1) Penetapan Sistem Jaringan Jalan}

Menurut Pasal 60 Peraturan Pemerintah Nomor 34 Tahun 2006 tentang Jalan, sistem jaringan jalan sebagai sistem jaringan jalan primer ditetapkan dengan keputusan

Menteri dengan
- menghubungkan jalan arteri/kolektor primer dengan kawasan sekunder kesatu (F2.1).

- lalu lintas cepat pada pada jalan arteri sekunder tidak boleh terganggu oleh lalu lintas lambat;

- kendaraan angkutan barang ringan dan bus untuk pelayanan kota dapat diijinkan melalu jalan ini;

- lokasi dan parkir pada badan jalan sangat dibatasi dan seharusnya tidak diijinkan pada jam sibuk.

2) Jalan kolektor sekunder adalah :

- menghubungkan antar kawasan sekunder kedua (F2.2);

- menghubungkan kawasan sekunder kedua (F2.2) dengan kawasan sekunder ketiga (F2.3);

- kendaraan angkutan barang berat tidak diijinkan melalui jalan ini di daerah permukiman;

- lokasi parkir pada badan jalan dibatasi.

3) Jalan lokal sekunder adalah:

- menghubungkan kawasan sekunder kesatu (F2.1) dengan perumahan;

- menghubungkan kawasan sekunder kedua (F2.2) dengan perumahan;

- menghubungkan kawasan sekunder ketiga (F2.3) dan seterusnya sampai ke perumahan;

- kendaraan angkutan barang berat dan bus tidak diijinkan melalui jalan ini di daerah permukiman.

4) Jalan lingkungan sekunder : menghubungkan antarpersil dalam kawasan perkotaan.

memperhatikan pendapat menteri yang menyelenggarakan urusan pemerintahan di bidang transportasi.

\section{2) Penetapan Fungsi Jalan}

Menurut Pasal 61 Peraturan Pemerintah Nomor 34 Tahun 2006 tentang Jalan:

a) Penetapan ruas-ruas jalan menurut fungsinya sebagai jalan arteri primer 
dan jalan kolektor primer yang menghubungkan antar ibukota provinsi dilakukan secara berkala dengan keputusan Menteri.

b) Penetapan ruas-ruas jalan menurut fungsinya dalam sistem jaringan jalan sekunder, jalan kolektor dalam sistem jaringan jalan primer selain dimaksud pada huruf a), jalan lokal dalam sistem jaringan jalan primer, serta jalan lingkungan dalam sistem

1) Kementerian Pekerjaan Umum dan Perumahan Rakyat telah menetapkan ruas jalan dalam sistem jaringan primer yang mempunyai fungsi sebagai Jalan Arteri (JAP) dan Jalan Kolektor Primer-1 (JKP1), dengan Keputusan Menteri Pekerjaan Umum dan Perumahan Rakyat Nomor: 248/KPTS/M/2015 tentang Penetapan Ruas Jalan Dalam Jaringan Jalan Primer Menurut Fungsimya Sebagai Jalan Arteri (JAP) dan Jalan Kolektor-1 (KP-1).

2) Gubernur Jawa Barat telah menentapkan ruas-ruas jalan dalam sistem jaringan primer yang mempunyai fungsi sebagai Jalan Kolektor 2 dan Kolektor 3 Primer, dengan Keputusan Gubernur Jawa Barat Nomor: 620/Kep. 293-Sarek/2007 tentang Penetapan Ruas-ruas Jalan Dalam Jaringan Primer Menurut Fungsinya Sebagai Jalan Kolektor 2, dan Kolektor 3, yaitu yang dimaksud dengan:

- Jalan kolektor 2 adalah: jalan yang menghubungkan Ibukota Provinsi dengan Ibukota Kabupaten atau Kota;

- Jalan Kolektor 3 adalah: jalan yang menghubungkan antar Ibukota Kabupaten/Kota.

3) Bupati Cianjur telah menetapkan status ruas jalan kabupaten Cianjur dengan Keputusan Bupati Cianjur Nomor : 620/Kep. 168-Binamarga/2013 Tentang Penetapan Status Ruas Jalan Kabuapaten Cianjur. Namun status ruas-ruas jalan tersebut belum ditetapkan fungsinya.

\section{FORMULASI HUBUNGAN ANTAR PUSAT KEGIATAN DENGAN JARINGAN JALAN}

Dari penjelasan mengenai system dan fungsi dari jaringan jalan serta mengenai fungsi jaringan jalan primer dilakukan secara berkala dengan Keputusan Gubernur, berdasarkan usul Bupati/wali kota yang bersangkutan dengan memperhatikan keputusan menteri sebagaimana dimaksud pada huruf a) dan berdasarkan pedoman yang ditetapkan Menteri.

\section{e. Penetapan Fungsi Jalan oleh Penyelenggara Jalan}

kawasana perkotaan yang dihubungkan oleh jaringan jalan, maka hubungan antara sistem, fungsi dan status jaringan jalan dengan fungsi kawasan perkotaan dapat dijelaskan sebagai berikut :

\section{a. Hubungan Struktur Hirarki Kawasan Perkotaan dan Sistem Jaringan Jalan Primer}

Matrik hubungan antara hirarki kawasan perkotaan dengan peranan ruas jalan penghubungnya dalam sistem jaringan jalan primer diperlihatkan pada Tabel 1 berikut:

Tabel 1. Hubungan Antara Hirarki Kota Dengan Peranan Ruas Jalan Penghubungnya Dalam Sistem Jaringan Jalan Primer

\begin{tabular}{|c|c|c|c|c|c|c|}
\hline PERKOTAAN & PKN & PKW & PKL & PPK & PPL & PERSIL \\
\hline \hline PKN & Arteti & Arteri & Kolektor & Lokal & Lokal & Lokal \\
\hline PKW & Arteri & Kolektor & Kolektor & Lokal & Lokal & Lokal \\
\hline PKL & Kolektor & Kolektor & Lokal & Lokal & Lokal & Lokal \\
\hline PPK & Lokal & Lokal & Lokal & Lokal & Lokal & Lokal \\
\hline PPL & Lokal & Lokal & Lokal & Lokal & Lokal & Lokal \\
\hline PERSIL & Lokal & Lokal & Lokal & Lokal & Lokal & Lingkungan \\
\hline
\end{tabular}

b. Hubungan Struktur Hirarki Kawasan Perkotaan dan Sistem Jaringan Jalan Sekunder

Matriks hubungan antara kawasan perkotaan dengan peranan ruas jalan penghubungnya dalam sistem jaringan jalan sekunder diperlihatkan pada Tabel 2 berikut:

Tabel 2. Hubungan Antara Hirarki Di Dalam Kawasan Perkotaan Dengan Peranan Ruas Jalan Penghubungnya Dalam Sistem Jaringan Jalan Sekunder 


\begin{tabular}{|c|c|c|c|c|c||}
\hline KAWASAN & $\begin{array}{c}\text { PRIMER } \\
(F 1)\end{array}$ & $\begin{array}{c}\text { SEKUNDER I } \\
(\text { F2.1 })\end{array}$ & $\begin{array}{c}\text { SEKUNDER } \\
\text { II (F2.2) }\end{array}$ & $\begin{array}{c}\text { SEKUNDER III } \\
(\text { F2.3) }\end{array}$ & PERUMAHAN \\
\hline \hline $\begin{array}{c}\text { PRIMER } \\
(F 1)\end{array}$ & - & Arteri & - & - & - \\
\hline $\begin{array}{c}\text { SEKUNDER I } \\
\text { (F2.1) }\end{array}$ & Arteri & Arteri & Arteri & - & Lokal \\
\hline $\begin{array}{c}\text { SEKUNDER II } \\
\text { (F2.2) }\end{array}$ & - & Arteri & Kolektor & Kolektor & Lokal \\
\hline $\begin{array}{c}\text { SEKUNDER III } \\
\text { (F2.3) }\end{array}$ & - & - & Kolektor & Lokal & Lokal \\
\hline PERUMAHAN & - & Lokal & Lokal & Lokal & Lokal \\
\hline
\end{tabular}

Diagram hubungan antara hirarki kawasan perkotaan dengan peranan ruas jalan penghubungnya dalam sistem jaringan jalan primer diperlihatkan pada Gambar 1 dan hirarki kawasan perkotaan dengan peranan ruas jalan penghubungnya dalam sistem jaringan jalan sekunder diperlihatkan pada Gambar 2 sebagai berikut:

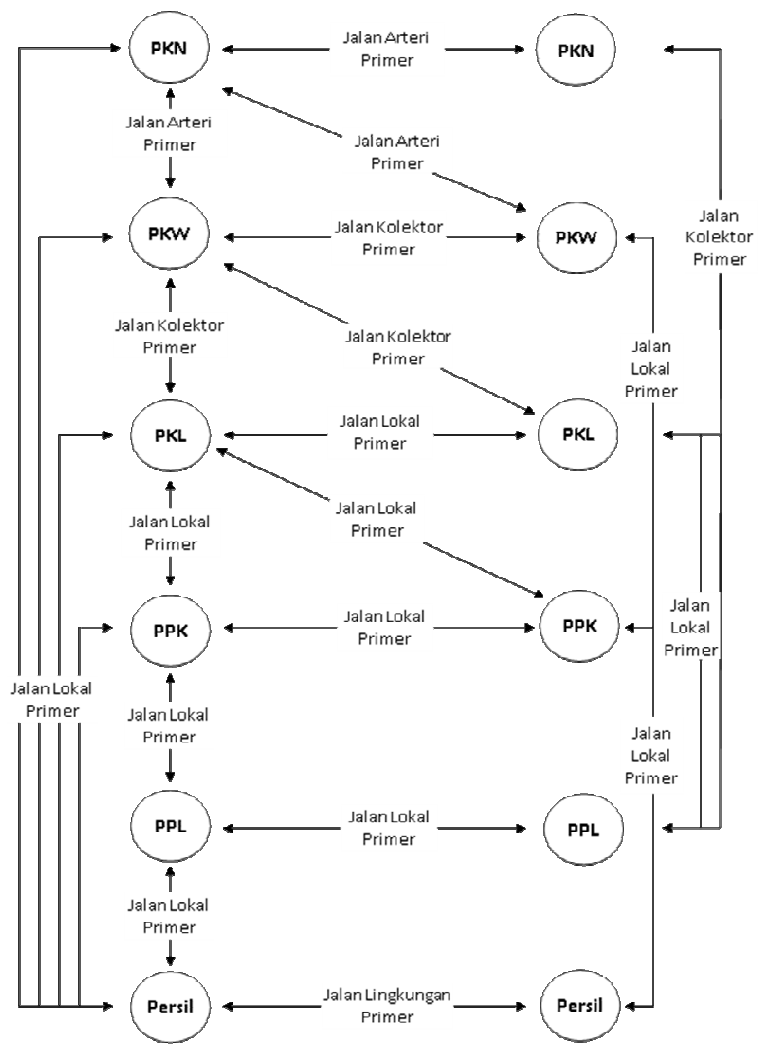

Gambar 1: Diagram Sistem Jaringan Jalan Primer

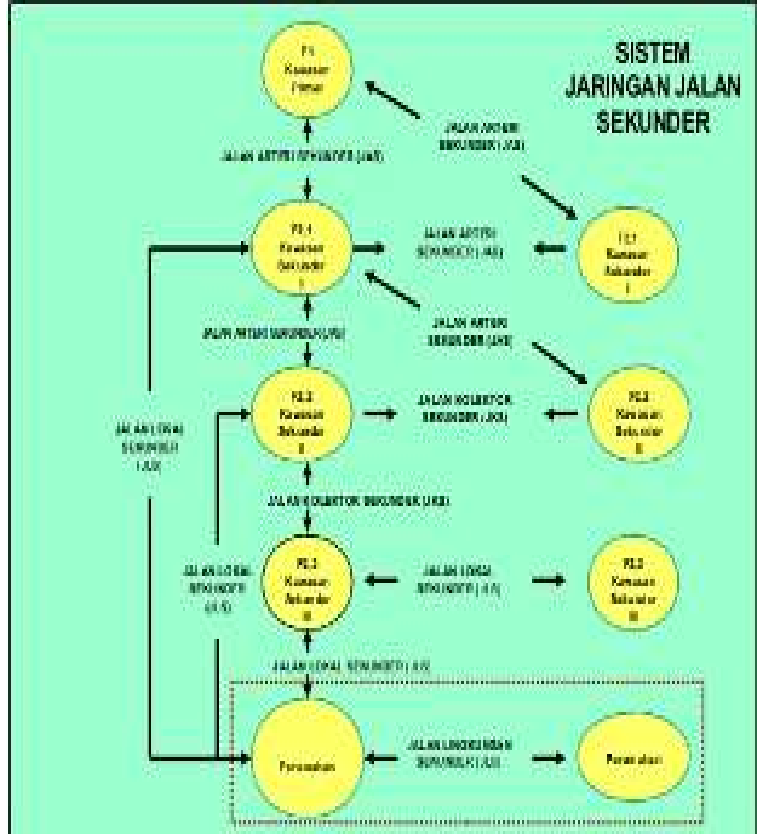

Gambar 2: Diagram Sistem Jaringan Jalan Sekunder

\section{Persyaratan Teknis (Kriteria Penetapan Klasifikasi Fungsi Jalan).}

Kriteria ini dimaksudkan sebagai ciriciri Umum yang diharapkan pada masingmasing fungsi jalan, dan merupakan arahan untuk fungsi jalan yang perlu dipenuhi/didekati. Berdasarkan Pasal 13 Peraturan Pemerintah Nomor 34 Tahun 2006 Tentang Jalan dan Pedoman Penentuan Klasifikasi Fungsi Jalan Di Kawasan Perkotaan Pd T-18-2004-B, persyaratan teknis jalan menurut fungsinya adalah sebagai berikut :

\section{a. Jalan Arteri Primer :}

1) didesain berdasarkan kecepatan rencana paling rendah 60 kilometer per jam;

2) lebar badan jalan paling sedikit 11 meter;

3) mempunyai kapasitas yang lebih besar dari volume lalu lintas rata-rata;

4) lalu lintas jarak jauh tidak boleh terganggu oleh lalu lintas ulang alik, lalu lintas lokal, dan kegiatan lokal;

5) jumlah jalan masuk ke jalan arteri primer dibatasi sedemikian rupa;

6) jalan arteri primer yang memasuki kawasan perkotaan dan/atau kawasan pengembangan perkotaan tidak boleh terputus. 


\section{b. Jalan Kolektor Primer}

1) didesain berdasarkan kecepatan rencana paling rendah 40 kilometer per jam;

2) lebar badan jalan paling sedikit 9 meter;

3) mempunyai kapasitas yang lebih besar dari volume lalu lintas rata-rata;

4) Jumlah jalan masuk dibatasi;

5) Jalan kolektor primer yang memasuki kawasan perkotaan dan/atau kawasan pengembangan perkotaan tidak boleh terputus.

\section{c. Jalan Lokal Primer}

1) didesain berdasarkan kecepatan rencana paling rendah 20 kilometer per jam;

2) lebar badan jalan paling sedikit 7,5 meter;

3) Jalan lokal primer yang memasuki kawasan perdesaan tidak boleh terputus;

\section{d. Jalan Lingkungan Primer}

1) didesain berdasarkan kecepatan rencana paling rendah 15 kilometer per jam;

2) lebar badan jalan paling sedikit 6,5 meter;

3) persyaratan teknis jalan lingkungan primer diperuntukkan bagi kendaraan bermotor beroda tiga atau lebih;

4) jalan lingkungan primer yang tidak diperuntukkan bagi kendaraan bermotor beroda tiga atau lebih harus mempunyai lebar badan jalan paling sedikit 3,5 meter.

\section{e. Jalan Arteri Sekunder}

1) didesain berdasarkan kecepatan rencana paling rendah 30 kilometer per jam;

2) lebar badan jalan paling sedikit 11 meter, sebagaimana pada Gambar 3;

3) kapasitas yang lebih besar daripada volume lalu lintas rata-rata;

4) lalu lintas cepat tidak boleh terganggu oleh lalu lintas lambat;

5) akses langsung dibatasi tidak boleh lebih pendek dari 250 meter;

6) persimpangan pada jalan arteri sekunder diatur dengan pengaturan tertentu yang sesuai dengan volume lalu lintasnya;

7) harus mempunyai perlengkapan jalan yang cukup seperti rambu, marka, lampu pengatur lalu lintas, lampu jalan, dan lainlain;

8) dianjurkan tersedia jalur khusus yang dapat digunakan untuk sepeda dan kendaraan lambat lainnya.
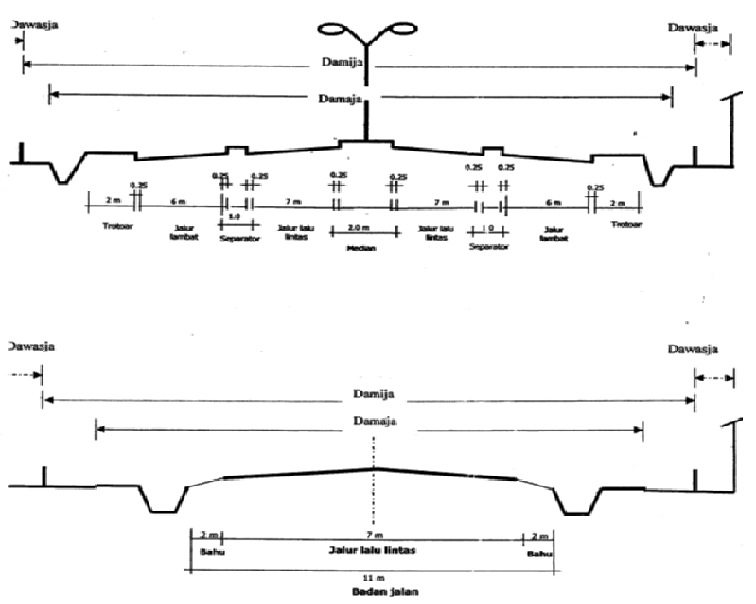

Gambar 3. Tipikal Penampang Melintang Jalan Arteri Sekunder

\section{f. Jalan Kolektor Sekunder}

1) didesain berdasarkan kecepatan rencana paling rendah 20 kilometer per jam;

2) lebar badan jalan paling sedikit 9 meter sebagaimana pada Gambar 4;

3) mempunyai kapasitas yang lebih besar daripada volume lalu lintas rata-rata;

4) lalu lintas cepat tidak boleh terganggu oleh lalu lintas lambat;

5) harus mempunyai perlengkapan jalan yang cukup.

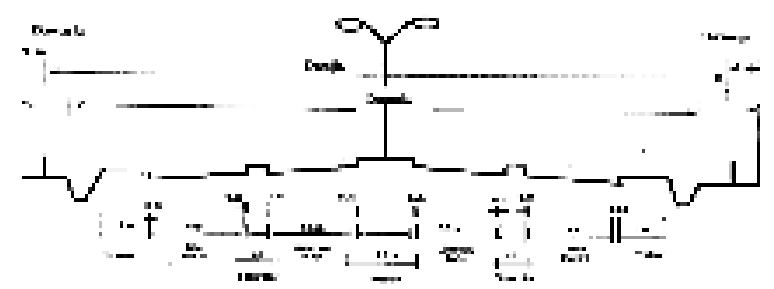

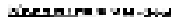

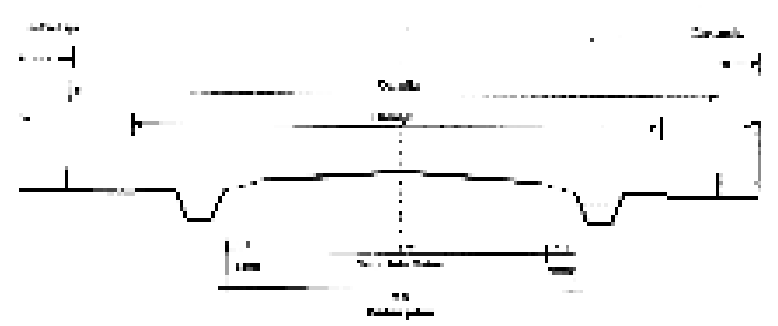

Gambar 4. Tipikal Penampang Melintang Jalan Kolektor Sekunder 


\section{g. Jalan Lokal Sekunder}

1) didesain berdasarkan kecepatan rencana paling rendah 10 kilometer per jam;

2) lebar badan jalan paling sedikit 6,5 meter, sebagaimana pada Gambar 5 .

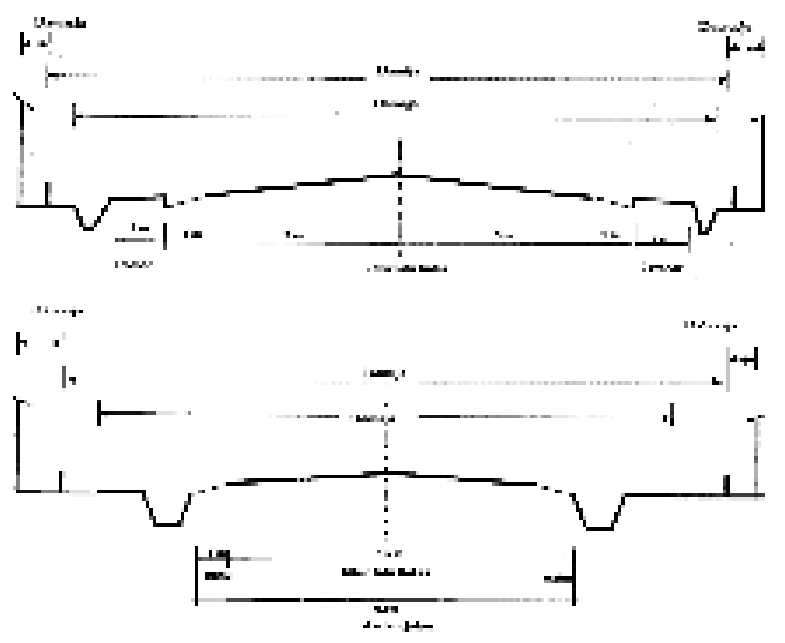

Gambar 5. Tipikal Penampang Melintang Jalan Lokal Sekunder

\section{h. Jalan lingkungan sekunder}

1) didesain berdasarkan kecepatan rencana paling rendah 10 kilometer per jam

2) lebar badan jalan paling sedikit 6,5 meter.

3) Persyaratan teknis jalan lingkungan sekunder diperuntukkan bagi kendaraan bermotor beroda 3 atau lebih.

4) Jalan lingkungan sekunder yang tidak diperuntukkan bagi kendaraan bermotor beroda 3 atau lebih harus mempunyai lebar badan jalan paling sedikit 3,5 meter.

\section{Evaluasi Terhadap Data Status Jalan Kabupaten Cianjur}

Berdasarkan data dari jaringan jalan kabupaten Cianjur sebagaimana Keputusan Bupati Cianjur Nomor 620/Kep. 160Binamarga/2013 Tentang Penetapan Status Ruas Jalan Kabupaten Cianjur, ruas-ruas jalan kanupaten tersebut belum ditetapkan sistem dan fungsi sebagaimana ketentuan yang tercantum dalam Peraturan Pemerintah Nomor 34 Tahun 2006 Tentang Jalan, dimana sebelum ditetapkan status jalan kabupaten dengan keputas Bupati, sistem dan fungsi jalannya terlebih dahulu harus ditetapkan oleh Gubernur berdasarkan usulan penentapan sistem dan fungsi jalan dari Bupati. Dapat dikatakan bahwa penetapan status jalan kabupaten tersebut tidak berdasarkan atas fungsi dari ruas-ruas jalan dalam melayani arus lalu lintas.

Oleh sebab itu dipandang perlu untuk dilakukannya peninjauan kembali Keputusan Bupati Cianjur Nomor 620/Kep. 160Binamarga/2013 Tentang Penetapan Status Ruas Jalan Kabupaten Cianjur, dan sebelum ditetapkan kembali status jalan kabupaten oleh Bupati Cianjur, terlebih dahulu fungsi jalan harus diusulkan oleh Bupati untuk ditetapkan oleh Gubernur Jawa Barat.

\section{Tahapan Penentuan Klasifikasi Fungsi Jalan di Kawasan Perkotaan}

Secara garis besar proses penentuan klasifikasi fungsi jalan di kawasaan perkotaan digambarkan dalam bagan alir sebagaimana pada Gambar 6 berikut:

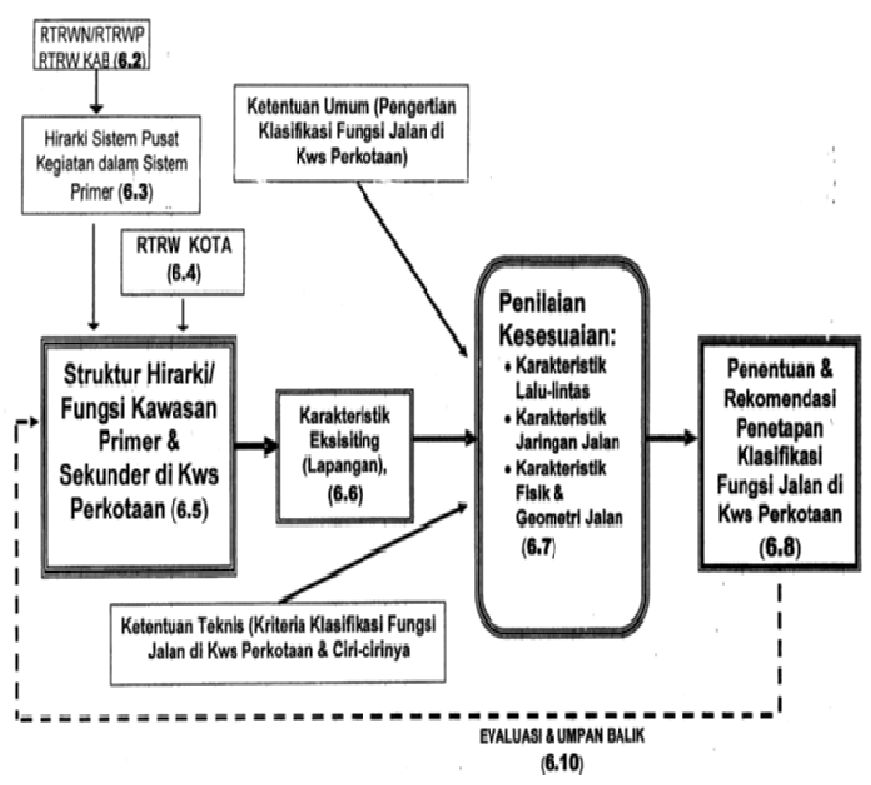

Gambar 6. Bagan Alir Proses Penentuan Klasifikasi Fungsi Jalan di Kawasan Perkotaan

Untuk menentukan klasifikasi fungsi dari ruas jalan perlu dilakukan tahapan-tahapan sebagai berikut:

a. Sebagai langkah awal penentuan klasifikasi fungsi jalan adalah melihat secara makro wilayah (nasional), dimana hubungan antara kota dengan kota yang lain. Hal ini sangat 
berguna untuk menentukan klasifikasi fungsi jalan primer.

b. Identifikasi pusat-pusat kegiatan di dalam rencana struktur ruang RTRW (Nasional, Propinsi maupun Kabupaten/Kota), yang telah ditentukan secara berhierarki satu sama lain yang dihubungkan oleh sistem jaringan transportasi. Penentuan pusat-pusat kegiatan ini didasarkan pada berbagai aspek pertimbangan, strategi dan kebijakan pengembangan dan pembangunan, pemanfaatan lahan (land use) saat ini, potensi yang ada dan kemungkinan perkembangan di masa yang akan datang.

c. Indikasikan pembagian Satuan Pengembangan Wilayah (SPW) dan strateginya serta klasifikasi/hirarki kota dalam satuan wilayah terkait. Dari kegiatan ini dapat diketahui fungsi-fungsi kota dalam suatu wilayah sebagai pusat-pusat kegiatan, misalnya Pusat Kegiatan Nasional (PKN), Pusat Kegiatan Wialayah (PKW), Pusat Kegiatan Lokal (PKL), Pusat Pelayanan Kawasan (PPK), dan Pusat Pelayanan Lingkungan (PPL).

d. Indikasikan jaringan jalan yang menghubungkan kota-kota tersebut di atas dengan kota lainnya guna menentukan sistem jaringan jalan tersebut termasuk dalam klasifikasi sistem jaringan primer.

e. Karena sistem jalan primer tidak terputus walaupun memasuki kawasan perkotaan, indikasikan lintasan sistem primer yang masuk dalam kawasan perkotaan.

f. Indikasikan fungsi jaringan jalan dalam sistem jaringan jalan primer tersebut diatas sesuai hirarkinya sebagai jalan arteri primer, kolektor primer, lokal primer, dan lingkungan primer dengan memperhatikan hirarki fungsi kota-kota yang dihubungkan oleh jaringan jalan primer tersebut.

g. Klasifikasi Fungsi Jalan pada Sistem Jaringan Jalan Sekunder

1) Untuk penentukan sistem jaringan jalan sekunder terlebih dahulu dengan memperhatikan RDTR masing-masing kawasan perkotaan, dimana di dalamnya terdapat sistem jaringan jalan yang sifat pelayanannya untuk mayarakat di dalam kawasan perkotaan itu sendiri. Hal ini berguna untuk penentuan klasifikasi sistem jaringan jalan sekunder.

2) Indikasikan pembagian fungsi-fungsi kawasan di tiap-tiap kota dan lakukan review kondisi saat ini dan kemungkinan perkembangan pada masa datang.

3) Indikasikan pusat-pusat kegiatan masyarakat dan hirarki masing-masing fungsi kawasan dalam kota tersebut sebagai fungsi kawasan primer (F1); kawasan sekunder satu (F2,1); kawasan sekunder dua $(\mathrm{F} 2,2)$; kawasan sekunder tiga $(\mathrm{F} 2,3)$; dan kawasan perumahan.

4) Indikasikan fungsi jaringan dalam sistem jaringan jalan sekunder sebagai jalan arteri sekunder, kolektor sekunder, lokal sekunder, dan lingkungan sekunder dengan memperhatikan hirarki fungsi kawasan yang dihubungkan oleh jaringan jalan sekunder tersebut.

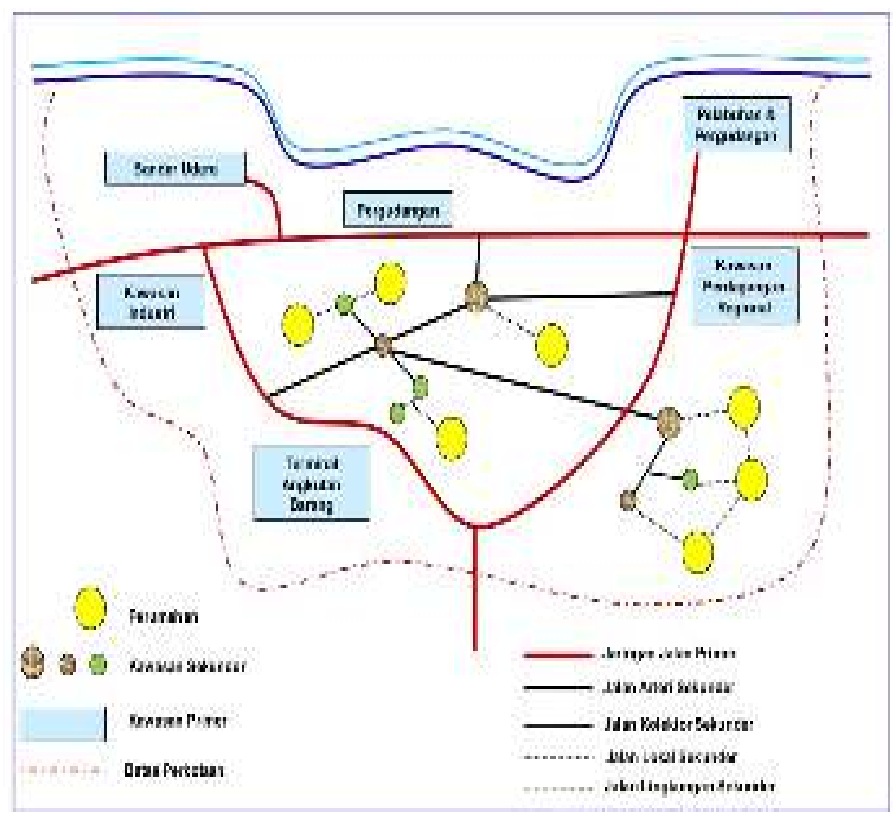

Gambar 6. Sketsa Jaringan Jalan di Kawasan Perkotaan

Jaringan jalan yang telah teridentifikasi fungsinya baik pada sistem jaringan primer maupun pada sistem jaringan jalan sekunder, selanjutnya direkomendasikan kepada instansi yang berwenang untuk ditetapkan fungsinya sesuai dengan Pasal 61 Peraturan Pemerintah Nomor 34 Tahun 2006 Tentang Jalan.

\section{Penentuan Klasifikasi Fungsi Jalan Sekunder di Kawasan Perkotaan Cianjur}


Untuk menentukan fungsi jaringan jalan pada sistem sekunder di kawasan perkotaan, sebagai studi kasus adalah kawasan perkotaan Cianjur. Adapun tahapan penentuan klasifikasi fungsi sekunder dikawasan perkotaan Cianjur adalah sebagai berikut:

a. Mempelajari pengertian sistem dan klasifikasi fungsi jalan berdasarkan Undangundang Nomor 38 Tahun 2004 tentang Jalan dan Peraturan Pemerintah Nomor 34 Tahun 2006 Tentang Jalan, serta Pedoman Penentuan Klasifikasi Fungsi Jalan Di Kawasan Perkotaan Pd T-18-2004-B.

b. Memahami kriteria klasifikasi fungsi jalan arteri, kolektor, lokal dan lingkungan di dalam sistem jaringan jalan primer dan sekunder.

c. Mengidentifikasi Rencana struktur ruang yang terdapat dalam RTRW Kabupaten Cianjur tahun 2011 - 2031 untuk mengindikasikan pusat-pusat kegiatan masyarakat di wilayah kabupaten Cianjur dan selanjutnya digunakan untuk menentukan ruas-ruas jalam dalam sistem primer. Skema rencana struktur ruang kabupaten Cianjur sebagaimana diperlihatkan pada Gambar 7 sebagai berikut.

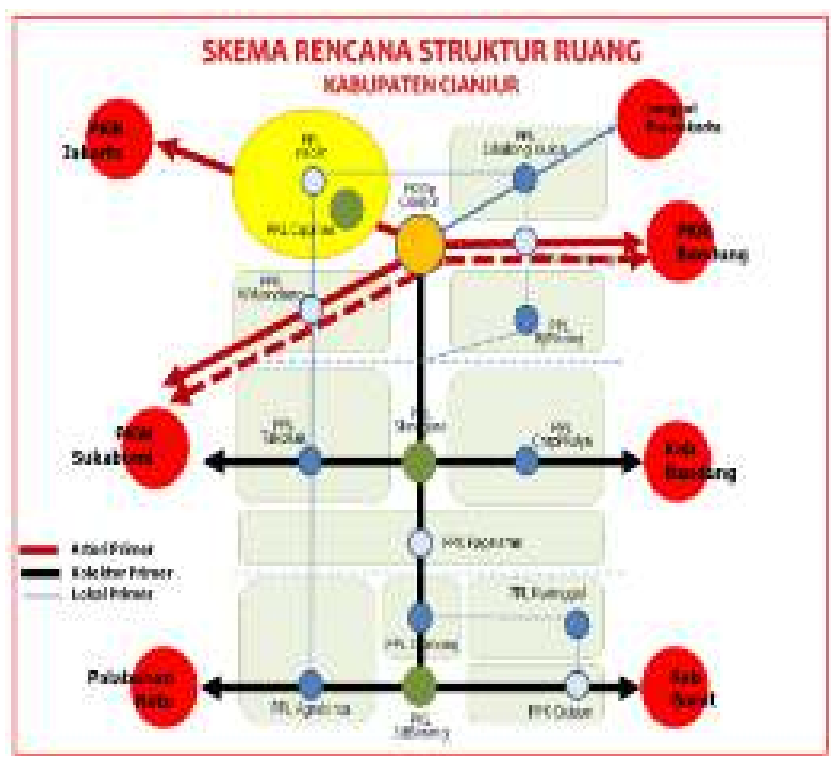

Sumber: RTRW Kabupaten Cianjur 2011 - 2031

Gambar 7: Skema Rencana Struktur Ruang Kabupaten Cianjur

d. Mengidentifikasi pola ruang di kawasan perkotaan di dalam RDTR kawasan perkotaan Cianjur tahun 2013 - 2033 untuk mengindikasikan hirarki zona-zona yang direncanakan di kawasan perkotaan Cianjur sebagai fungsi kawasan primer (F1); kawasan sekunder satu $(\mathrm{F} 2,1)$; kawasan sekunder dua $(\mathrm{F} 2,2)$; kawasan sekunder tiga $(\mathrm{F} 2,3)$; dan kawasan perumahan. Zona-zona tersebut meliputi:

1) Fungsi Kawasan Primer (F1), yaitu:

- Zona perdagangan dan jasa skala regional (kabupaten) berlokasi di Pasirhayam Desa Sirnagalih atau di blok C.2 berupa pasar induk, pusat perdagangan, pergudangan, rumah toko, dan toko;

- Zona sarana pelayanan umum, meliputi:

- Sarana pendidikan skala kabupaten berupa sarana Pendidikan Tinggi di Pasirgede Raya dan Jalan Dr. Muwardi blok D.1, Jalan Abdullah Bin Nuh blok A.5 dan blok E.1 serta di Jalan Perintis Kemerdekaan blok C.2;

- sarana kesehatan skala kabupaten milik pemerintah daerah yaitu berupa Rumah Sakit Umum Daerah (RSUD) Kabupaten Cianjur di Kelurahan Bojongherangblok D.1 dan Rumah Sakit Paru di Kelurahan Pamoyanan blok A.4;

- Rencana pembangunan lapangan oleh raga terbuka dan lapangan olah raga tertutup skala pelayanan kabupaten berupa sport center di Desa Sukamajublok C.2 seluas kurang lebih $300.000 \mathrm{~m}^{2}$ (tiga ratus ribu meter persegi);

- Zona aneka industri berada di Jalan Pramuka blok B.2 berupa jenis industri pengolahan bahan sandang, dan di Jalan Perintis Kemerdekaan blok C. 2 berupa jenis industri pengolahan kulit;

- Terminal type B atau terminal utama ditempatkan pada tempat/simpul yang saling terhubung dengan sistem jaringan jalan, yaitu di Kmp. Pasirhayam Desa Sirnagalih Kecamatan Cilaku blok C.2 seluas kurang lebih $21.300 \mathrm{~m}^{2}$ (dua puluh satu ribu tiga ratus meter persegi). 
2) Fungsi kawasan sekunder satu $(\mathrm{F} 2,1)$, yaitu:

- Zona perdagangan dan jasa skala pelayanan kota (BWP) berupa pasar tradisional Pasar Muka di blok A.1 Kelurahan Muka dan pusat perbelanjaan serta toko modern di sepanjang Jalan Mangunsarkoro, Jalan HOS Cokroaminoto, Jalan Siti Jenab, Jalan Dr. Muwardi, Jalan Siliwangi, Jalan Suroso, Jalan Moch Ali dan Jalan Abdullah Bin Nuh;

- Zona sarana pelayanan umum, meliputi:

- Sarana pendidikan tingkat kota berupa sarana pendidikan Tingkat Menengah (SMU/SMK/MA) tersebar di Jalan Pangeran Hidayatulloh, Jalan Abdullah Bin Nuh, Jalan Siliwangi, Jalan Pasundan, dan Jalan Perintis Kemerdekaan;

- Sarana kesehatan skala pelayanan kota yaitu berupa Puskesmas dan Puskesmas Pembantu di Jalan Pangeran Hidayatulloh kompleks Kopem Kelurahan Sawahgede blok A.5, Jalan Dr. Muwardi Kelurahan Muka blok D.1, Desa Babakankaret blok D.1, Desa Rancagoong blok E.1, dan di Desa Bojong blok B.2;

- Sarana pendudukung kesehatan skala pelayanan kota seperti apotik, toko obat, dan laboratorium di Jalan Ir. H. Juanda, Jalan HOS Cokroaminoto, dan Jalan Dr. Muwardi;

- Sarana peribadatan skala regional dan kota meliputi Mesjid Agung yang berada di Jalan Siti Jenab (Taman Alun-alun), Gereja Protestan Indonesia (GPI) di Jalan Mangunsarkoro, Gereja Santo Petrus di Jalan Siliwangi, dan Gereja Huria Kristen Batak Protestan (HKBP) di Jalan Mangunsarkoro, Gereja Kristen di Jalan Moch. Ali, Gereja Pentakosta di Indonesa (GPDI) di Jalan Hasyim Ashari, Kelenteng Bhumi Pharsija di Jalan Mangunsarkoro;
- lapangan olah raga terbuka skala pelayanan kota yaitu lapangan Prawatasari dan Stadion Badak Putih dan lapangan olah raga tertutup berupa Gelanggang Generasi Muda (GGM) Panembong Desa Limbangansari dan Gedung Wisma Karya di Kelurahan Sayang.

- Terminal type $\mathrm{C}$ atau sub-terminal ditempatkan di masing-masing sub BWP yaitu di Kmp. Warungseuseupan untuk melayani angkutan umum dari arah Bogor/Cipanas, di Kmp. Rawabango blok B.3 untuk melayani angkutan arah Bandung/Ciranjang/Cikalongkulon, dan di Kmp. Pasirhayam Desa Sirnagalih Kecamatan Cilaku blok C.2 untuk melayani angkutan dari arah Warungkondang dan Cibeber yang bersatu dengan terminal type $\mathrm{B}$.

3) Fungsi kawasan sekunder dua $(F 2,2)$, yaitu:

- Zona perdagangan dan jasa skala pelayanan kawasan (Sub BWP) dikembangkan di Desa Bojong (Sub BWP B), Warungbatu Desa Mekarsari (Sub BWP D), Desa Sukamaju (Sub BWP C) dan Desa Rancagoong (Sub BWP E), yaitu berupa pasar tradisional, toko modern, rumah toko dan toko;

- Zona sarana pelayanan umum, meliputi:

- Sarana pendidikan tingkat tingkat kawasan berupa sarana pendidikan Tingkat Pertama (SMP/MTs) tersebar diseluruh kawasan kota;

- sarana kesehatan skala pelayanan kecamatan yaitu berupa Puskesmas dan Puskesmas Pembantu yaitu di Jalan Pangeran Hidayatulloh (kompleks Kopem Kelurahan Sawahgede), Jalan Dr. Muwardi (Kelurahan Muka), Desa Babakankaret, Desa Rancagoong, dan di Desa Bojong;

- sarana peribadatan skala kecamatan/kawasan berupa mesjid jami dan sarana peribadatan skala lingkungan berupa musholla dan 
langgar yang tersebar di seluruh kawasan kota.

4) Fungsi kawasan sekunder tiga (F2,3), yaitu:

- Zona perdagangan dan jasa skala pelayanan lingkungan dikembangkan secara merata di seluruh pusat lingkungan yang menyatu dengan kawasan permukiman, berupa toko dan warung;

- Zona sarana pelayanan umum, meliputi:

- Sarana pendidikan tingkat lingkungan berupa sarana pendidikan Tingkat Dasar (SD/MI) dan sarana pendidikan Pra Sekolah (TK/PAUD) tersebar diseluruh kawasan kota;

- sarana kesehatan skala pelayanan lingkungan berupa Pustu, Pokesdes, dan Posyandu yang tersebar diseluruh kawasan perkotaan;

- sarana peribadatan skala lingkungan berupa musholla yang lokasinya menyatu dengan permukiman;

- lapangan olah raga terbuka dan lapangan olah raga tertutup skala lingkungan tersebar di seluruh kawasan perkotaan yang menyatu dengan lingkungan permukiman.

5) Fungsi kawasan perumahan, yaitu:

- Zona perumahan kepadatan tinggi di seluruh Sub BWP A, sebagian di Sub BWP B dan sebagian di Sub BWP D;

- Zona perumahan kepadatan sedang meliputi kawasan permukiman yang masih berdekatan dengan pusat kota yang tersebar di sebagian Sub BWP B, di sebagian Sub BWP C, di sebagianSub BWP D dan di sebagianSub BWP E;

- Zona perumahan kepadatan rendah meliputi kawasan perumahan di daerah penggiran perkotaan atau di sebagian Sub BWP B, di sebagian Sub BWP C, di sebagian Sub BWP D dan di sebagian Sub BWP E.
Rencana pembagian blok wilayah perencanaa kawasan perkotaan Cianjur sebagaimana diperlihatkan pada Gambar 8 sebagai berikut.

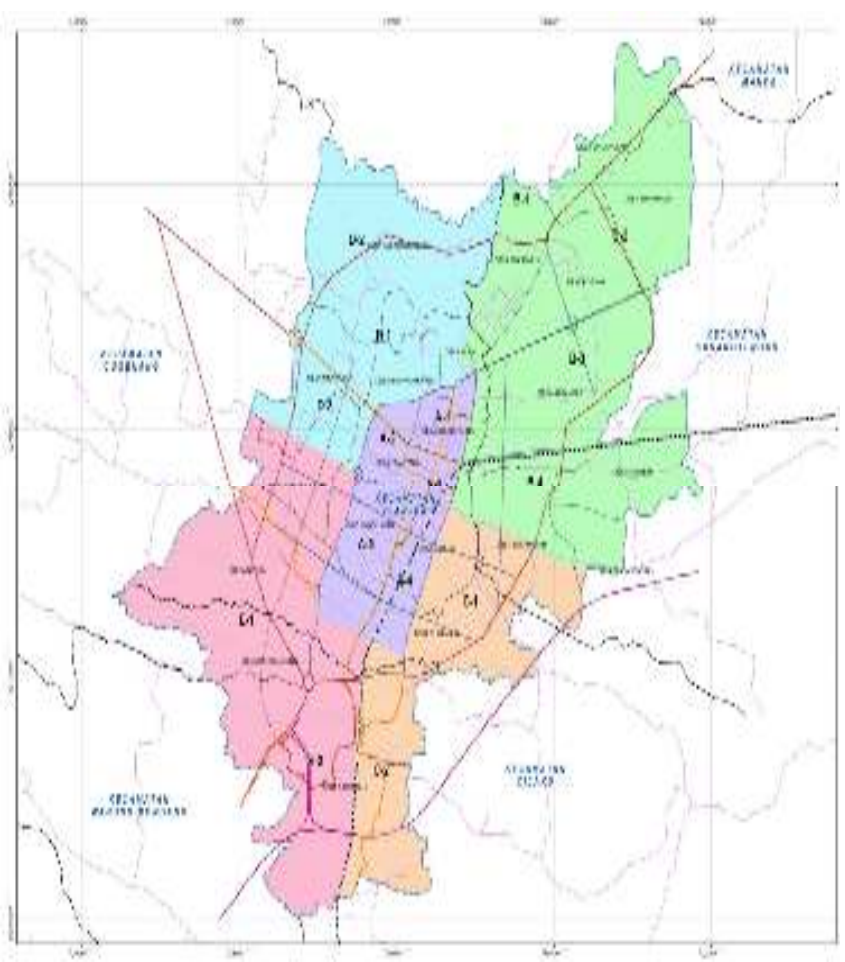

Gambar 8. Pembagian Blok Wilayah Perencanaan Kawasan Perkotaan Cianjur

e. Mengidentifikasi jaringan jalan yang menghubungkan fungsi-fungsi kawasan perkotaan yang telah diindikasikan sebagai fungsi kawasan primer (F1); kawasan sekunder satu (F2,1); kawasan sekunder dua $(\mathrm{F} 2,2)$; kawasan sekunder tiga $(\mathrm{F} 2,3)$; dan kawasan perumahan;

f. Dengan diketahuinya hirarki fungsi kawasan perkotaan Cianjur, berdasarkan pengertian klasifikasi fungsi jalan yang terdapat pada sistem jaringan sekunder, maka dapat diidentifikasi klasifikasi fungsi jalan yang ada yaitu terdiri dari arteri sekunder (AS), kolektor sekunder (KS) dan lokal sekunder (LS). Matriks hirarki fungsi jaringan jalan sistem sekunder di kawasan perkotaan Cianjur ditampilkan pada Tabel 3 sebagai berikut. 
Tabel 3. Hubungan Antara Hirarki Fungsi Kawasan Perkotaan Cianjur Dengan Peranan Ruas Jalan Penghubungnya Dalam Sistem Jaringan Jalan Sekunder

\begin{tabular}{|c|c|c|c|c|c|}
\hline $\begin{array}{c}\text { FUNGSI } \\
\text { KAWASAN }\end{array}$ & $\begin{array}{l}\text { PRIMER } \\
\text { (F1) }\end{array}$ & $\begin{array}{l}\text { SEKUNDER I } \\
\text { (F2.1) }\end{array}$ & $\begin{array}{l}\text { SEKUNDER } \\
\text { II (F2.2) }\end{array}$ & $\begin{array}{c}\text { SEKUNDER III } \\
(\mathrm{F} 2.3)\end{array}$ & \multirow[b]{2}{*}{ PERUMAHAN } \\
\hline Blok & $\begin{array}{l}\text { A-4, A-5, } \\
\text { B-2, C-2, } \\
\text { D-1, E-1 }\end{array}$ & A-1, A-5, B-3, & $\begin{array}{c}\text { Kawasan di } \\
\text { Sub BWP B, } \\
\text { C, D, E }\end{array}$ & $\begin{array}{l}\text { Seluruh pusat } \\
\text { lingkung }\end{array}$ & \\
\hline PRIMER (F1) & & $\begin{array}{l}\text { Arteri Sekunder } \\
\text { (AS): } \\
\text { - Jl. }\end{array}$ & & & \\
\hline $\begin{array}{l}\text { A-4, A-5, B-2, } \\
\text { C-2, D-1, E-1 }\end{array}$ & - & $\begin{array}{l}\text { Mangunsarkoro; } \\
\text { - Jl. HOS } \\
\text { Cokroaminoto; } \\
\text { - Jl. Siti Jenab; } \\
\text { - Jl. Siliwangi; } \\
\text { - Jl. Abdullah Bin } \\
\text { Nuh; } \\
\text { - Jl. Jl. KH. } \\
\text { Hasyim Ashari } \\
\end{array}$ & & - & - \\
\hline $\begin{array}{l}\text { SEKUNDER I } \\
(\mathrm{F} 2.1)\end{array}$ & & $\begin{array}{l}\text { Arteri Sekunder } \\
\text { (AS): }\end{array}$ & & & $\begin{array}{l}\text { Lokal Sekunder } \\
\text { (LS): }\end{array}$ \\
\hline A-1, A-5, B-3, & $\begin{array}{c}\text { Idem } \\
\text { Arteri } \\
\text { Sekunder } \\
\text { (F1) ke } \\
\text { (F2.1) }\end{array}$ & $\begin{array}{l}\text { - Jl. Ir. H. Juanda; } \\
\text { - Jl. P. } \\
\text { Hidayatulloh. } \\
\text { - Jl. Rumah Sakit; } \\
\text { - Jl. Pasirgede } \\
\text { Raya; } \\
\text { - Jl. Jl. Taifur } \\
\text { Yusuf; } \\
\text { - Jl. Amalia } \\
\text { Rubini } \\
\text { - Jl. Muka I - II - } \\
\text { III } \\
\text { - Jl. A. Hanapiah } \\
\text { - Jl. H. Agus } \\
\text { Saleh } \\
\text { - Jl. Guru Isa } \\
\text { - Jl. Dewi Sartika } \\
\text { - Jl. Barisan } \\
\text { Banteng } \\
\text { - Jl. Suroso; } \\
\text { - Jl. Moch Ali; } \\
\text { - Adi Sucipta; } \\
\text { - Jl. Moch. Ali; } \\
\text { - Jl. Amalia } \\
\text { Rubini; } \\
\text { - Jl. Suroso } \\
\text { - Jl. Taifur Yusuf } \\
\text { - Jl. Otto } \\
\text { Iskandardinata II } \\
\text { - Jl. Slamet } \\
\text { Riyadi } \\
\text { - Jl. Aria } \\
\text { Cikondang }\end{array}$ & $\begin{array}{c}\text { Idem } \\
\text { Arteri } \\
\text { Sekunder } \\
\text { (F2.2) ke } \\
\text { (F2.1) }\end{array}$ & - & $\begin{array}{l}\text { - Jl. Komp. SMP 2; } \\
\text { - Jl. Gn. Gede } \\
\text { - Jl. Lika Santiong } \\
\text { - Jl. Kpt. Bahrudin } \\
\text { - Jl. Dipawangi } \\
\text { - Jl. Suryakencana } \\
\text { Kopem } \\
\text { - Jl. Perwira } \\
\text { - Jl. Yulius Usman } \\
\text { - Jl. Moch. Abbas } \\
\text { - Jl. Ibu Atikah } \\
\text { - Jl. Kh Syaban } \\
\text { - Jl. Moch. Toha } \\
\text { - Jl. Mayor Harun } \\
\text { Kabir } \\
\text { - Jl. Slamet } \\
\text { - Jl. Otista I } \\
\text { - Jl. Otista III } \\
\text { - Jl. Imun Sulaeman } \\
\text { - Jl. Kapten Musa }\end{array}$ \\
\hline
\end{tabular}




\begin{tabular}{|c|c|c|c|c|c|}
\hline & & $\begin{array}{l}\text { - Jl. Psr } \\
\text { Baru/Ruko } \\
\text { - Jl. Kh. Asnawi }\end{array}$ & & & \\
\hline $\begin{array}{l}\text { SEKUNDER II } \\
(\mathrm{F} 2.2)\end{array}$ & \multirow[b]{2}{*}{ - } & \multirow{2}{*}{$\begin{array}{l}\text { Arteri Sekunder } \\
\text { (AS): } \\
\text { - Jl. Aria. } \\
\text { Wiratanudatar } \\
\text { - Jl. Kh Saleh }\end{array}$} & \multirow[b]{2}{*}{-} & \multirow{2}{*}{$\begin{array}{c}\text { Kolektor } \\
\text { Sekunder (F2.3) } \\
\text { ke (F2.2) }\end{array}$} & \multirow{2}{*}{$\begin{array}{l}\text { Lokal Sekunder } \\
\text { (LS): } \\
\text { - Jl. Hisbullah } \\
\text { - Jl. Moch. Noch } \\
\text { - Jl. Rsm.Tangerang } \\
\text { - Jl. Cicih Witarsih }\end{array}$} \\
\hline $\begin{array}{c}\text { Kawasan di } \\
\text { Sub BWP B, C, } \\
\text { D, E }\end{array}$ & & & & & \\
\hline $\begin{array}{l}\text { SEKUNDER } \\
\text { III (F2.3) }\end{array}$ & \multirow{2}{*}{-} & \multirow{2}{*}{ - } & \multirow{2}{*}{ - } & \multirow{2}{*}{-} & \multirow{2}{*}{-} \\
\hline $\begin{array}{l}\text { Seluruh pusat } \\
\text { lingkung }\end{array}$ & & & & & \\
\hline PERUMAHAN & - & $\begin{array}{c}\text { Idem Lokal } \\
\text { Sekunder (F2.1) } \\
\text { ke Perumahan }\end{array}$ & $\begin{array}{l}\text { Idem Lokal } \\
\text { Sekunder } \\
\text { (F2.2) ke } \\
\text { Perumahan }\end{array}$ & - & $\begin{array}{l}\text { Lokal Sekunder: } \\
\text { Jl. Rancabali }\end{array}$ \\
\hline
\end{tabular}

Jawa Barat mengenai fungsi jalan di wiIayah Kabupaten Cianjur sesuai

\section{Kesimpulan dan Saran}

1) Perlu dilakukannya peninjauan kembali Keputusan Bupati Cianjur Nomor: 620/Kep. 168Binamarga/2013 Tentang Penetapan Status Ruas Jalan Kabuapaten Cianjur, karena status jalan kabupaten yang ditetapkan tidak dilengkapi dengan fungsi dari ruas-ruas jalan.

2) Perlu ditetapkan fungsi-fungsi ruas jalan yang berada di wilayah kabupaten Cianjur melalui Keputusan Gubernur Jawa Barat di luar ruas-ruas jalan yang telah ditetapkan fungsinya melalui Keputusan Menteri Pekerjaan Umum dan Perumahan Rakyat Nomor: 248/KPTS/M/2015 tentang Penetapan Ruas Jalan Dalam Jaringan Jalan Primer Menurut Fungsimya Sebagai Jalan Arteri (JAP) dan Jalan Kolektor1 (KP-1) dan Keputusan Gubernur Jawa Barat Nomor: 620/Kep. 293Sarek/2007 tentang Penetapan Ruasruas Jalan Dalam Jaringan Jalan Primer Menurut Fungsinya Sebagai Jalan Kolektor 2, dan Jalan Kolektor 3.

3) Perlu ditetapkan kembali status jalan Kabupaten Cianjur oleh Bupati setelah di keluarkannya keputusan Gubernur
4)

5) dengan Peraturan Pemerintah Nomor 34 Tahun 2006 tentang Jalan.

\section{Daftar Pustaka}

1) Republik Indonesia "Undang-undang Republik Indonesia Nomor: 38 tahun 2004 tentang Jalan".

2) Republik Indonesia "Undang-undang Republik Indonesia Nomor: 26 tahun 2007 tentang Penataan Ruang".

3) Republik Indonesia "Peraturan Pemerintan Republik Indonesia Nomor: 34 tahun 2006 tentang Jalan".

4) Republik Indonesia "Peraturan Pemerintah Republik Indonesia Nomor: 26 tahun 2008 tentang Rencana Tata Ruang Wilayah Nasional.

5) Kementerian Agraria Dan Tata Ruang/Kepala Badan Pertanahan Nasional "Peraturan Menteri Agraria Dan Tata Ruang/Kepala Badan Pertanahan Nasional Nomor 1 Tahun 2018 Tentang Pedoman Penyusunan 
Rencana Tata Ruang Wilayah Provinsi, Kabupaten Dan Kota.

6) Kementerian Agraria Dan Tata Ruang/Kepala Badan Pertanahan Nasional "Peraturan Menteri Agraria Dan Tata Ruang/Kepala Badan Pertanahan Nasional Republik Indonesia Nomor 16 Tahun 2018 Tentang Pedoman Penyusunan Rencana Detail Tata Ruang Dan Peraturan Zonasi Kabupaten/Kota".

7) Kementerian Pekerjaan Umum" Keputusan Menteri Pekerjaan Umum dan Perumahan Rakyat Nomor: 248/KPTS/M/2015 tentang Penetapan Ruas Jalan Dalam Jaringan Jalan Primer Menurut Fungsimya Sebagai
Jalan Arteri (JAP) dan Jalan Kolektor1 (KP-1)".

8) Kementerian Pekerjaan Umum "Pedoman Penentuan Klasifikasi Fungsi Jalan di Kawasan Perkotaan Pd T-18-2004-B”.

9) Kementerian Pekerjaan Umum "Peraturan Menteri Pekerjaan Umum Nomor: 03/Prt/M/2012 Tentang Pedoman Penetapan Fungsi Jalan Dan Status Jalan".

Propinsi Jawa Barat "Keputusan Gubernur Jawa Barat Nomor: 620/Kep. 293-Sarek/2007 tentang Penetapan Ruas-ruas Jalan Dalam Jaringan Jalan Primer Menurut Fungsinya Sebagai Jalan Kolektor 2, dan Jalan Kolektor 3". 